museum as Hunter left it contained 13,682 preparations arranged in two divisionsnormal structures and abnormal structures ; now the number of preparations has been doubled, though the museum is still only an expansion of Hunter's. Over and over again-notably in 1835, 1847, and 1888the college has added new buildings to accommodate the ever-increasing collections, and in the successive conservators it has appointed-W. Clift, Richard Owen, J. T. Quekett, William Flower and Charles Stewart-it has had the good fortune to find men of the highest scientific attainments who have watched over them with unceasing care. To the first of these, admirers of Hunter are specially indebted, for he was the means of preserving a great part of Hunter's anatomical writings. Originally included with the collections, they were borrowed by Sir E. Home, Hunter's executor, who used them for the manufacture of papers and lectures, to which he attached his own name, and then burnt them so as to remove the evidence of his dishonorable conduct. Clift, however, had made copious extracts from the MSS., and in this way an authentic record of about half their substance has been preserved. The college possesses many memorials of Hunter, including a very fine portrait of him by Sir Joshua Reynolds, his consulting chair, clock, pocket-scales, lancet-case, etc. His ' name and fame' are celebrated by a biennial 'Hunterian Oration,' while numerous Hunterian lectures are delivered in accordance with the conditions on which the collections were entrusted to the college. Another service rendered to the cause of surgical knowledge by the college is to be found in the splendid library it has formed and maintains. This originated in a small grant of $£ 50$ made at the very beginning of this century; it now contains 50,000 volumes, including journals and transactions of scientific societies. Finally, reference must be made to the college's important share in examining and licensing physicians and surgeons to practice. This portion of its functions is carried on jointly with the Royal College of Physicians-a return to an arrangement 400 years old-the examinations being mostly held in the examination hall built on the Thames Embankment in 1886 , at the joint expense of the two bodies. Here not only is medical knowledge tested but its sum increased, for the hall includes extensive laboratories for original research, where materials are supplied at the expense of the colleges to any of their Fellows or members who obtain permission to work in them. In addition anti-toxic serum is prepared for the hospitals of the Metropolitan Asylums Board and for various general and children's hospitals, the cost of the latter supply being defrayed by a grant from the Goldsmiths' Company.

\section{THE DEVELOPMENT OF SURGERY.*}

ONE hundred years have passed since the charter granted by King George III. incorporated the surgeons of England into a Royal College, whereby the art and science of surgery might be the better cultivated and the commonweal of the people of this kingdom benefited.

We meet to-day in order to celebrate the centenary of our incorporation, and the occasion compels us to reflect how far the College has fulfilled its high mission and merited the public consideration and confidence it enjoys, and, as we believe, deserves to enjoy, through unselfish service to the State.

My first and most pleasant duty is to welcome our illustrious guests who have come from many and distant countries to do honor to our College. Amongst them

\footnotetext{
* Address of welcome on the occasion of the centenary festival of the Royal College of Surgeons of England, delivered by the president, Sir Willlam MacCormac and published in the Rritish Medical Journal.
} 
are great surgeons from almost all nations, men who not only hold the highest professional position in their respective countries, but whose public record has made their name familiar to us all, while many of them are dear personal friends.

We have guests, too, our own countrymen, whom we delight to honor, dignitaries of the Church and of the Law, and heads of our ancient seats of learning. Although I cannot enumerate all, I can and do extend to each and every one the most cordial welcome, and would wish to express our grateful appreciation of their presence amongst us.

An occasion like this possesses historic interest. We contrast our present position with that of our predecessors, and rightly congratulate ourselves on our greater knowledge and opportunities, on the facilities we enjoy for investigating the mystery of disease, and for its more effective treatment.

The comparison enables us to realize, as only such a comparison can, the extent of our gains and our increased opportunities for doing good. It leads us at the same time to recognize, as we ought, how large a debt we owe to the workers who have preceded us for so many of those happy results which are now matters of daily accomplishment.

The progress of surgery has been greater during the present century, more especially in the latter portion of it, than in all the preceding centuries combined, and it is of especial interest to us to note that this period of rapid advancement exactly corresponds with the life-history of our College, whose Centenary we are assembled to commemorate.

If we look back-and it is well to look back sometimes-we find in the labors of the old masters of surgery much to enlighten, to widen, and to confirm our views. A knowledge of the history of our art and science tends to make us juster judges both of our own work and that of others.
When we search the history of the development of scientific truth we learn that no new fact or achievement ever stands by itself, no new discovery ever leaps forth in perfect panoply, as Minerva did from the brow of Jove.

Absolute originality does not exist, and a new discovery is largely the product of what has gone before.

We may be confident that each forward step is not ordered by one individual alone, but is also the outcome in a large measure of the labors of others. The history of scientific effort tells us that the past is not something to look back upon with regret-something lost, never to be recalled-but rather as an abiding influence helping us to accomplish yet greater suocesses.

Again and again we may read in the words of some half-forgotten worthy the outlines of an idea which has shone forth in later days as an acknowledged truth.

We see numerous instances of this in the history of surgery. Some fellow-worker in years long past has discovered a new fact or indicated the path leading to a fresh truth. It is forgotten, and a century later something nearly the same, or mayhap a little better, is discovered afresh. The psychological moment has arrived, and the discoverer reaps the reward, not only of his own labors, but of those of his predecessors as well.

The countless trials and experiments which ended in the general use of ether and chloroform in surgery, that treblyblessed discovery of a sure relief from pain, were guided by the experience of previous trials, half successful, half failures.

The patient labor of our distinguished Fellow, Lord Lister, now President of the Royal Society, has been rewarded by a success to which all the world does homage, and which will crown his head with imperishable laurels. Yet none will be readier than Lord Lister to acknowledge how much the antiseptic methods of wound treatment 
owe to the researches and discoveries of Pasteur.

If we examine the old books we may find again and again something very near to what is the accepted doctrine of the present time. History, it is said, repeats itself, and so very certainly does surgery. The difficulty of discovering anything new is as great in surgery as in other branches of knowledge. Hippocrates (460 B. C.), the Father of Medicine, classified injuries of the skull in much the same way as that adopted in our modern text-books. He spoke of contusions of the cranium without fracture or depression, of simple fractures, depressed fractures, indented fractures involving the outer table alone, and fractures at a distance from the seat of injury which we now style fractures by contre-coup, a classification which leaves but a small mairgin for improvement.

Many of the surgical instruments found in Pompeii are precisely similar in principle, if not quite equal in workmanship, to those now in use, and Pompeii was destroyed 1800 years ago (A. D. 79).

Heliodorus, who lived at the beginning of the second century A. D., in the time of the Emperor Trajan, was a surgeon of much originality, and appears to have been familiar with some of our modern methods and discoveries. He knew, for instance, of the ligature of arteries, of the radical cure of hernia by extirpation of the sac, and of the excision of a rebellious stricture of the urethra.

Oribasius, who flourished in the middle of the fourth century, A. D., was the friend and physician of the Emperor Julian. $\mathrm{He}$ has preserved for us the work of Antyllus, whose treatment of aneurysm by ligature of the vessel above and below the sac, with subsequent incision and evacuation of its contents, has of late years been revived with success, and is still considered by many of our surgeons as the best method of treat- ment in certain cases. One might cite other examples of old methods consciously or unconsciously revived, but these may perhaps suffice.

The modern specialist finds his prototype in very ancient times, and what we are apt to regard as a recent development is in reality a survival. Herodotus tells us that in Egypt there were as many branches of the profession as there are parts of the human body.

In Europe, until the rise of the Italian Universities, surgery was mainly in the hands of peripatetic charlatans, who cut for stone and operated on hernia. They travelled from town to town, kept their methods secret, and handed them down as family property to their descendants.

The Hippocratic oath restricted the performance of lithotomy to those who had especially devoted their whole energies to the cultivation of this operation, and may partly serve to explain this remarkable survival. Some of these ' cutters' were skilful men, but all were of necessity very ignorant.

A very famous ' cutter,' whose name we do not know, died in Genoa in 1510, and Senerega, the Genoese historian, tells us that his method was to introduce an iron rod along the urethra into the bladder until it touched the stone, which he then extracted through a perineal wound. It has been suggested that this Genoese taught his method to John of Cremona, who is credited with the invention of the grooved staff.

One of the most celebrated 'cutters' was Pierre Franco, who was born in Provence about 1500, A. D. He used a staff and cut on the gripe as well, and employed instruments for the purpose of crushing large stones. He was a man of determination and resource, for he relates a case of a boy in whom having failed to remove a stone by way of the perineum, he successfully performed the suprapubic operation. 
The stone was the size of a hen's egg, and the patient subsequently made a good recovery.

Colot was appointed lithotomist to the Hôtel Dieu of Paris in 1556. He had learnt what is known as the 'Marian operation' from an itinerant quack, and he practiced the method with, it is said, much success. The office and the secret descended to his son and to his grandson.

In the great Metropolitan Hospitals-in St. Bartholomew's and St. Thomas's for instance-persons were at one time specially appointed for the purpose of cutting for stone.

John Bamber, who lived during the reigns of William III., Queen Anne, George I. and George II., was the last of the special lithotomists at St. Bartholomew's. He resigned his office in 1730 and his duties were transferred to the surgeons of the hospital, who were specially paid a small stipend each year as lithotomist until 1868. Bamber's portrait by Verelst may be seen at Hatfield House, and Lord Salisbury inherits some portion of his property through an heiress of this line who married a Marquess of Salisbury.

At St. Thomas's Hospital certain of the surgeons were specially appointed to cut for stone, but before the year 1730 there appears to have been a special 'surgeon for the stone,' and the first of these was James Molins, who held a similar office at St. Bartholomew's. There is, indeed, no end to the matters of interest in the history of our art.

The great French surgeon, Guy de Chauliac, who was born about 1300 A. D., studied at the three most famous centers of learning of that time-Bologna for anatomy, Paris for its surgery, and Montpelier for medicine. He travelled much, but finally settled at Avignon, where he became physician in succession to Pope Clement VI., and afterwards to Pope Innocent and Urban. It was in Avignon that he wrote his ' Great Surgery,' and in a special chapter of this work he records opinions which have an application even in the circumstances of our own times. "Formerly," he says, " all medical writers were both physicians and surgeons-that is to say, well educated men ; but since then surgery has become a separate branch and fallen into the hands of mechanics."

It is interesting to find from Guy that there were in his day exponents of that modern foolishness called 'Christian Science.' These Guy describes as ' consisting of women and many fools.' They refer the sick of all diseases to the saints, saying :

Le Seigneur me l'a donné ainsi qu'il Lui a plu. Le Seigneur me l'ostera quand il Lui plaira, le nom du Seigneur soit benit. Amen.

As a striking instance of my thesis I may take the great French military surgeon, Ambroise Paré. We know his title to fame in substituting the ligature of arteries for the use of the hot iron in the arrest of hæmorrhage. We know also the story of how he forbade the barbarous practice of pouring boiling oil into gunshot wounds, due to the then prevailing belief that these wounds were poisoned, a belief revived with almost every war, even the latest war in South Africa. Paré had been apprenticed to a provincial barber at the age of 9 . Soon afterwards he came to Paris, attended lectures at the Faculty of Medicine, and gained admission to the Hôtel Dieu. He lived there as a dresser for three years, ' seeing and knowing a great variety of diseases constantly being brought there.' He was only 19 when he accompanied the King, François I., into Provence to meet the army of Charles V. He was attached to the Courts of four Kings of France, and, although a Huguenot, was spared at the Massacre of St. Bartholomew by the direct intervention of Charles IX.

It is interesting to learn that Dionis, more than one hundred years after Paré's time, 
was urging at the Hôtel Dieu the adoption of arterial ligature in place of the caustic even then in vogue. Dionis too, although he advised the Marian operation for stone, considered that the risks of the suprapubic method had been overestimated, an opinion revived and insisted on by Sir Henry Thompson in our own time.

We all remember J. L. Petit (1674-1750), who invented the tourniquet known by his name in the early part of the last century, and Anel, who tied the branchial artery for traumatic aneurysm at the bend of the elbow, upon which procedure a claim was based for priority over Hunter, though Hunter's operation is wholly distinct in the principle in volved.

Towards the end of the eighteenth century Desault, who nearly lost his life in the Revolution, was the leading French surgeon. He was accused of poisoning the wounds of some of his revolutionary patients in the Hôtel Dieu, and to be accused was in those times almost the same thing as being condemned. Desault, whose fame has been eclipsed by the brilliance of his pupil Bichat, was the first surgeon to teach surgical anatomy after the modern manner, although the great French hospital where he practiced was described at that time as ' the oldest, largest, richest, and worst hospital in Europe.' I need not refer to more recent and greatly honored names-Dupuytren, Velpeau, Nélaton, and many others.

In Germany, even so recently as 100 years ago, surgery was at a low ebb. George Fischer tells us that quacks of all kinds, 'cutters' for stone and hernia, cataract operators, and bonesetters, flourished in the land. The public executioner, whose business it was to fracture bones and dislocate joints on the rack, was supposed thereby to have acquired a knowledge of disorders of these parts, and was consulted freely about them-so much so that Frederick the Great in 1744 published a decree limiting the powers of these men, and while permitting them to treat fractures, wounds and ulcers, forbade them to practice medicine. Hildanus (1560-1634), who lived in Germany at the end of the sixteenth and beginning of the seventeenth century, has been called the Father of German surgery. He was a voluminous writer, a bold operator and his Opera Omnia was a work of reference for many years. Heister (1683-1758), a surgeon of much note in the eighteenth century, wrote a General Surgery, which enjoyed much repute, and was translated into English. Bilguer (1720-1796), a surgeongeneral in the German army was noted for opposing the indiscriminate amputation of limbs then in vogue for gunshot fracture of the extremities, which his predecessor Schmucker had warmly advocated and practiced to an inordinate extent.

Towards the end of the eighteenth century Von Siebold (1736-1807), a famous surgeon, who enjoyed great repute as a clinical teacher and operator, taught anatomy at Würzburg and about the same time Richter (1742-1812) was Professor of Surgery at Göttingen. Richter had travelled much, was familiar with the work done in England and France, and was the best writer and teacher of his day. He was the first to place surgery in Germany on a truly scientific basis. Of those German surgeons whose names still fill our ears with their fame, and whose loss we have recently deplored - Stromeyer, Langenbeck, Billroth, Volkmann, Thiersch, Nussbaum and others-I could only repeat what all of you know as well as or better than I.

The first English surgeon of whom we possess any definite knowledge, and whose writings are still in existence, is John of Arderne. He was born in 1307. He must have been an accurate and close observer, to judge by the graphic description he furnishes of cancer of the rectum. He says : 
It breeds within the fundament with great hardness, but with little pain. After a time it is ulcerat, oftentimes all the circumference, and the excrement goeth out continuallie.

He gives a true and telling description of how the condition is to be diagnosed, and of the progress and termination of the disease.

It is noteworthy how many of the older surgeons who attained eminence spent part of their career in the army or navy. William Clowes (1540-1604), who was Surgeon to St. Bartholomew's, had been surgeon in the navy, and wrote $A$ Proved Practice for all Young Chirurgeons concerning Burnings with Gunpowder and Wounds made with Gunshot, and he refers to Ambroise Paré in terms of admiration.

The greatest English surgeon of the seventeenth century was Richard Wiseman (1622-1676). He served in the Dutch navy till 1644, and then entered the army of Charles I. 'Afterwards he spent three or four years in the Spanish navy, and on the Restoration joined the forces of Charles II., by whom he was appointed one of his surgeons. He published many treatises, which exercised a considerable influence on English surgery, but were little known abroad.

William Cheselden (1688-1752) was a surgeon of great renown in England in the early part of the eighteenth century. He was Surgeon and Lecturer at St. Thomas's Hospital. In 1723 he published a treatise on the high operation for stone, but he soon abandoned this for the lateral method, which he so much perfected and improved that the operation remains at the present time much as he left it.

Percivall Pott (1714-1788) was the famous English surgeon of the middle portion of the last century. He was Surgeon to St. Bartholomew's Hospital, and made many and most important contributions to surgery, especially on hernia and on injuries to the head. His name remains attached to many surgical disorders.
Of John Hunter (1728-1793) no detailed mention is required here. His memory and his methods continue a living influence amongst us. He made our surgery a science, and has given to us in our Museum an imperishable memorial of his industry. In it are illustrated those marvellous powers of observation which had never before been equalled, and will never in all probability be surpassed. So long as surgery continues, Hunter's influence must be felt. It is witnessed in the creation of so many distinguished disciples imbued with his principles and able to expound his doctrines. He embodies and represents the glory of our science, our College, and our country.

The historical summary I have attempted would not be complete without some account of the connection existing between the Surgeons and the City of London, which appears to have continued quite without interruption since the middle of the fourteenth century until the foundation of the Surgeons' Company in 1745. There are many entries in the City records of the admission by the Lord Mayor of surgeons and master surgeons to practice in the City of London, and the license thus granted exacted a promise " that they should well and truly serve the people in their cures, and report to the Lord Mayor and Aldermen any surgeon neglecting his patients."

In 1416 the Craft of Barbers practising surgery petitioned the Lord Mayor and Aldermen " to provide a sure remedy against unskilful persons who indiscreetly pretended to be wiser than the Masters of Surgery, and who expose the sick to the greatest danger of death or maim by their presumption." The City took immediate and, as we learn, successful action on this petition.

The City recognized the distinction between barbers and surgeons, for they appointed masters of surgery to control those practising surgery only, and other masters were annually selected to super- 
vise those practising barbery. Early in the fifteenth century the surgeons appear as a distinct body, and in 1423 a College of Physicians and Surgeons, which had been founded chiefly through the influence of John Morstede, a surgeon who accompanied Henry V. to Agincourt, was formally sanctioned by the Lord Mayor, and powers granted to it to examine and control persons practising medicine and surgery in the City of London. The Livery Company of Barber-Surgeons was founded in 1540, and its Hall in Monkswell Street is still standing, and it escaped destruction in the Great Fire of London. The famous picture of Hans Holbein of Henry VIII. delivering the Charter of the Company to the assembled barber-surgeons is still there, where until recently one might see the old theater, where lessons in anatomy were read upon the bodies of executed malefactors.

Thomas Vicary (149(?)-1561), SergeantSurgeon to the King, the first Master of this Company, was a wise and honest gentleman. He held a unique position at St. Bartholomew's, and there is in Holbein's picture at the Barber Surgeons' Hall a characteristic portrait of him. Vicary was succeeded by Thomas Gale(1507-1587), who had served with the army of Henry VIII. in France in 1544, and under Philip II. of Spain in 1577. In his Institutions of Chirurgeons there is an account of wounds made by gunshot. He opposed the view that they are poisoned, and gives cases to prove that bullets may be left for long in the body without danger.

The Barber-Surgeons appear to have borne their due share in the City pageants. At one given at the Restoration, the Lord Mayor and aldermen appointed that the Company should provide "twelve of the most grave and comlyest personages, appareled with velvet coats, sleeves of the same, and chaynes of gold, to attend the Lord Mayor on horseback."
Mr. Edward Arris, an Alderman and Barber-Surgeon, had a great desire to increase the knowledge of Chirurgery, and to this intent bequeathed to the Company a sum to found lectures, in 1645, on anatomy, on condition that a ' humane' body should once in every year be publicly dissected. The Gale Lecture was founded by John Gale a little later, in 1655, and Havers, well known for his description of the canals in bone, since called Haversian, was appointed the first reader. The Arris and Gale Lectures are still annually delivered in this College, for when the Surgeons finally separated from the Barbers in 1745 they carried nothing with them but the Arris and Gale bequests. The hall, library, and plate remained the property of the Barbers, and the new Company of Surgeons had to make a fresh start in the world.

The Act of Parliament separating the Surgeons from the Barbers became a law in 1745, and a Corporation was established consisting of a master, governors, and Commonalty of the Art and Science of Surgery in London.

John Ranby, one of the prime movers in effecting the change, became the first Master. He was Sergeant-Surgeon to George II., and accompanied that monarch to the battle of Dettingen in 1743. The other active mover was Cheselden, Surgeon to Queen Charlotte's, to Chelsea, and St. Thomas's Hospitals. The first meeting of the new Company was held in the Stationers' Hall, July 1, 1745. Mr. Ranby, as Master, occupied the chair, and Mr. Cheselden and Mr. Sandford were his wardens.

Ten examiners were appointed to conduct the examinations of those seeking the diploma of the newly-constituted Company, and this number is continued in the present Court of Examiners. Part of their duty was to examine surgeons for His Majesty's army and navy, and the examination of 
surgeons for those services, which had been instituted in the reign of Henry VIII., was continued for a long time by the Court of Examiners until other arrangements were made at a comparatively recent date. It was for this examination, I may note in passing, that Oliver Goldsmith presented himself in order to qualify as a naval surgeon's mate, December 21, 1758. He was unsuccessful, and it was well perhaps, since he could scarcely have written The Vicar of Wakefield in the cockpit of a manof-war. In Roderick Random we possess a graphic and probably fairly correct description of one of these examinations, derived, doubtless, from Smollett's personal experience, as he obtained the Company's diploma for a post of surgeon in His Majesty's navy.

The Surgeons established themselves in the Old Bailey, and there they built a theater. In 1753 Percivall Pott and John Hunter were chosen as the first Masters in Anatomy, and no more brilliant choice could have been made. It is recorded that immediately after this election the Court proceeded to discuss how they should dispose of the bodies of three persons who were to be executed a few days afterwards for ' murder,' and then sent to the College theater to be dissected. Amongst these brought in this way was that of Lord Ferrers, executed in 1760 for killing his steward. It was not, however, dissected, but buried in Old St. Pancras Churchyard at the intercession of Lady Huntington.

On July 7, 1796, Henry Cline the elder was elected a member of the Court, but, as it subsequently turned out, the meeting at which this occurred was irregular, and its proceedings illegal, a properly constituted quorum not being present. Although only a technical illegality had taken place, this incident led to the final extinction of the Company of Surgeons, for a bill shortly afterwards introduced into Parliament to legalize the proceeding was thrown out, and the Company was thereupon dissolved. The bill passed the Commons, but was rejected in the Lords, mainly through the influence of Lord Thurlow, who was bitterly opposed to Mr. Gunning, a very distinguished surgeon, and at the time Master. " There is no more science in surgery," Lord Thurlow is reported to have said, "than there is in butchery." "Then," replied Gunning, "I heartily pray your lordship may break your leg and have only a butcher to set it, and my lord will then find out the difference between butchery and surgery."

In 1796 the Surgeons migrated from the Old Bailey to Lincoln's Inn Fields. In that year a new bill they sought for was rejected in the Lords on the ground that the College premises were too far removed from the place of execution, and that it would be indecent and improper to carry the bodies of deceased criminals so long a distance through the streets of London. Finally, the Court in 1797 decided to apply to the Crown, and not to Parliament, for a new charter, and, although opposition was again offered, it proved unsuccessful, and March 22,1800 , the Royal College of Surgeons in London was established by charter of King George III. This charter gave the College its former rights on condition of resigning its municipal privileges. The titles of Master and Governors were retained for a time, but a supplementary charter from King George IV. in 1821 replaced these by those of President and Vice-Presidents. In 1843 another charter, granted by Her Majesty Queen Victoria, changed the title to that of ' Royal College of Surgeons of England,' with a President, two Vice-Presidents, Council, Fellows, and Members, as they exist at the present time. Thus it was that the Royal College of Surgeons of England was created.

During the century of its existence this College has witnessed discoveries which have profoundly changed the character of 
surgical practice and the scope of surgical aspirations. An immense development has been effected in the operative surgery of every region of the body, and the victories of the surgeon over disease and death are without end.

John Hunter, and many of the older surgeons, regarded operations as somewhat of an opprobrium to surgery, and as a confession of failure. How far otherwise it is now! Intracranial, intrathoracic, and intra-abdominal operations are successfully carried out, many of them by proceedings which had never previously been imagined, even by the boldest amongst us. A great impetus has been given to conservative methods in surgery, and the preservation of life and limb is now attainable in cases innumerable, and of the most different description, where conservation was previously regarded as impossible.

How largely also have physicians and surgeons alike developed and cultivated that highest form of conservation, the conservation of the race in the happiness and vigor which are associated with physical health!

Plastic methods have been perfected in an extraordinary degree. I would only mention as a striking, although common example, the union of the ends of an accidentally divided nerve and the re-establishment of its function.

Although the number and variety of operations have multiplied a hundredfold, the skill and fertility of resource exhibited in their performance have equally increased and the measure of success which has been realized, whilst it rewards and gratifies the surgeon, will appear even to the educated layman as little short of miraculous. In the early part of the century the surgeon knew of but a limited number of operations, and for the most part those only were performed which appeared to be inevitable. He knew by sad expèrience how generally fatal important operations and cases of severe injury were when treated in hospital wards. His patients were more then decimated by infective diseases-pyæmia, septicæmia, erysipelas, tetanus, and by suppuration, hectic and gangrene. He recognized and could to some extent control these scourges, but of any effective manner of dealing with them he knew nothing. Now we possess an intimate knowledge of the essential causes of many of these diseases, and if we cannot always cure them we can do much to prevent them. Some things have hitherto baffled our efforts. The cause and the cure of cancer are as yet unknown. We possess some crude ideas about the exciting causes of the disease, and attempt with indifferent success to cure it by timely extirpation. Let us hope that the new century will still be young when some surer means of dealing with this terrible and increasing malady is discovered.

A notable feature of our time is the development of the museums which are now attached to most of our public institutions. Those which more immediately concern ourselves illustrate everything within the range of biological science, and foremost amongst them all is our own great collection.

Much more might one say-and much certainly there is to say-but I will only repeat that our welcome to you all is sincere and heartfelt, and most especially so to our foreign colleagues. Our science knows no narrow national boundary. It is the common property of us all. We desire to sympathize with our fellow-workers abroad, and to appreciate their work, as we trust and believe that they appreciate ours.

In this address $I$ have ventured to urge that we are much beholden to those who have gone before. In but a few years all who are now present will also belong to the past. Let us hope that, as we have not altogether forgotten those who preceded us, 
we too may be remembered a little by those who are to follow.

On great occasions like the present, the older seats of learning and other public institutions had power to grant honorary distinctions. Formerly we possessed no such faculty, but by the act of Her Gracious Majesty we, too, have recently obtained permission to grant a certain number of Honorary Fellowships of this College. The Fellowship is the greatest distinction it is in our power to bestow, and we regard it as the highest purely surgical qualification obtainable in this country. It is, therefore, a great privilege and pleasure for me to present, on behalf of this College, this high honor to those distinguished men who are about to receive it.

I am sure also all present will be gratified to learn that His Royal Highness the Prince of Wales has graciously consented to become the first of our Honorary Fellows. His Royal Highness has always shown his interest in the College, and has evinced a special care for the success of its Centenary. It is quite fitting, therefore, that his Royal Highness, who is the patron of so many learned and scientific societies, should add the lustre of his name to the Royal College of Surgeons of England.

William MacCormac.

\section{CHEMISTRY AT THE NEW YORK MEETING} OF THE AMERICAN ASSOCIATION.

As has been the practice for a number of years Section $C$ met throughout the New York meeting in joint session with the American Chemical Society. The sessions took place in Havemeyer Hall, Columbia University, with the exception of those on the second day of the meeting, which were held at the Chemists' Club of New York City by special invitation of its officers.

At the opening session of the Section, after the election of the usual officers, a report of the Committee on Indexing Chemical Liter- ature was presented,in which the completion of some new important indexes was announced. This report has been already published in this Journal. A resolution relating to the establishment of a National Standards Bureau, submitted by the President of the American Chemical Society, was endorsed by the Section and referred to the Council of the Association.

The address of the Vice-President, Dr. Jas. Lewis Howe, on the 'Eighth Group of the Periodic System and some of its Problems,' has been already published in full in Sorence (see the July 6th number).

A large number of valuable scientific papers were presented. As is always the case, many of them, though important, were of a specialized or technical character. Only a few of those having a more general interest can be referred to here.

First may be mentioned the address of Dr. W. A. Noyes on the 'Structure and Configuration of Camphor and its Derivatives,' consisting of a historical review of the previous work bearing on the subject and a brief account of his own remarkable and difficult syntheses of compounds closely related to camphor, and of the establishment of their identity with products obtained directly from it. By his investigations, the correctness of the formulæ for camphor and camphoric acid suggested by Bouveault and Perkin respectively, viz :<smiles>CC1(C)CCC2CC(=O)C2(C)C1(C)CC1(C)CCC(C(=O)O)C1(C)C(=O)O</smiles>

seems to have been placed beyond a reasonable doubt. Two other points connected with the investigation deserve special mention ; first, the isolation of an optically active acid containing no asymmetrical carbon atom, its activity being due to the asymmetrical structure of a ring containing a double-union ; and, second, the method 